\title{
A review of the main drivers and variability of Central America's Climate and seasonal forecast systems
}

\author{
Tito Maldonado ${ }^{1 *}, 2$, Eric J. Alfaro ${ }^{2,3,4}$ \& Hugo G. Hidalgo $0^{2,4}$ \\ 1. Department of Earth Sciences, Uppsala University, Villavägen 16, 75236 Uppsala, Sweden; \\ tito.maldonado@geo.uu.se \\ 2. Centro de Investigaciones Geofísicas, Universidad de Costa Rica, 2060 San José, Costa Rica; hugo.hidalgo@ucr.ac.cr \\ 3. Centro de Investigaciones en Ciencias del Mar y Limnología, Universidad de Costa Rica, 2060 San José, Costa Rica; \\ erick.alfaro@ucr.ac.cr \\ 4. Escuela de Física, Universidad de Costa Rica, 2060 San José, Costa Rica
}

$$
\text { Received 16-I-2017. Corrected 03-VII-2017. Accepted 03-I-2018. }
$$

\begin{abstract}
Central America is a region susceptible to natural disasters and climate change. We reviewed the literature on the main atmospheric and oceanographic forces and climate modulators affecting Central America, for different spatial and time scales. We also reviewed the reported correlation between climate variability, natural hazards and climate change aspects (in the past and future). In addition, we examined the current state of seasonal prediction systems being applied to the region. At inter-annual scales, El Niño/Southern Oscillation is the main climate modulator; however, other indices such as the Tropical North Atlantic, Atlantic Multi-Decadal Oscillation and Pacific Decadal Oscillation, have shown a correlation with precipitation anomalies in the region. Current seasonal forecast systems in the region have shown a constant development, including incorporation of different approaches ranging from statistical to dynamical downscaling, improving prediction of variables such as precipitation. Many studies have revealed the need of including -in addition to the climatic informationsocio-economic variables to assess the impact of natural disasters and climate change in the region. These studies highlight the importance of socio-economic and human life losses associated with the impacts caused by natural hazards for organizations and governments. Rev. Biol. Trop. 66(Suppl. 1): S153-S175. Epub 2018 April 01.
\end{abstract}

Key words: Natural threats, seasonal climate prediction, climate variability, climate change.

Central America is a region regularly affected by natural threats. The source of these catastrophes covers a vast variety of natural hazards associated with its geographic location such as: prolonged cyclonic seasonality from both the Caribbean Sea and Pacific Ocean, geomorphology, and threats of hydro-meteorological origin (Pérez-Briceño, Alfaro, Hidalgo, \& Jiménez, 2016). This region has a persistent occurrence of isolated large-scale phenomena or a combination of them, generating physical damage and economical losses. For example, not only intense, less frequent extreme events cause devastation in the region, but also high frequency meteorological events of lower intensity can cause most of the impacts in the region (Oficina de las Naciones Unidas para la Reducción del Riesgo de Desastres [UNISDR] \& Centro de Coordinación para la Prevención de los Desastres Naturales en América Central [CEPREDENAC], 2014). In fact, Retana (2012) found that the indirect effect of hurricanes over Central America causes extreme precipitation, with higher frequency of occurrence from September to November, and major impact over the Pacific slope. A secondary mechanism of rainfall production identified were cold surges (Retana, 2012; Alfaro \& Pérez-Briceño, 2014; Pérez-Briceño et al., 2016), affecting mainly the north and the Caribbean sides of Costa Rica and Honduras from December to January. Retana (2012) reported low pressure systems that 
occur between April to November was another source of extreme precipitation; however, their effects are more homogeneous over the region.

Natural threats, however, depend on the degree of vulnerability of the exposed elements, as well as, the phenomenon's occurrence and adaptation capacity (Muñoz et al., 2012; Neri \& Magaña, 2016). Alfaro, Quesada, \& Solano-Chaves (2010); Hidalgo \& Alfaro (2012), and Pérez-Briceño et al. (2016) found that the recent increment of annual impacts due to hydro-meteorological events cannot be explained without including socio-economic variables. In addition, the complex topography of the region requires that the study of climatic effects must be approached from a regional perspective.

To understand better the impacts of natural threats, mainly related to hydrometeorological hazards, the objectives of this paper are twofold: a) to review the main atmospheric and oceanic forces and climate modulators affecting Central America and their connection to climate variability and change. In addition, b) to examine the current seasonal prediction systems implemented in the region.

\section{MATERIALS AND METHODS}

We reviewed the literature on the main atmospheric and oceanographic forces and climate modulators affecting Central America, for different spatial and time scales. The structure of this review is organized accordingly to the aims of the paper. In the first half, the main climate features and climate variability responses are revised. The second half of the paper will be focused on the seasonal forecast system currently tested and implemented by Central American institutions. The appendix 1 presented a list of abbreviations used in this review.

\section{RESULTS AND DISCUSSION}

\section{Climatic features of Central America}

The geographical location of Central America plays a significant role in describing the climate variability of the region. Surrounded by two large water masses, the Eastern Tropical Pacific (ETPac) ocean on the western side (Fiedler \& Lavín, 2006), and the Caribbean Sea on the eastern side, along with the Gulf of Mexico, the entire area is known as the IntraAmericas Sea (IAS) (Amador, 2008) as shown in Fig. 1. The IAS also plays an important role in the global climate, because it receives large amounts of radiation coming from the Sun onto the Earth surface, and this regional waters act like an energy reservoir.

The IAS region is sensitive to the effect of both large-scale and regional-scale dynamical systems acting in its vicinity. The most dominant synoptic influence over the IAS region is the North Atlantic Subtropical High (NASH) (Taylor \& Alfaro, 2005; Amador, Alfaro, Lizano, \& Magaña, 2006; Amador, Rivera, et al., 2016). Subsidence associated with the spreading of the subtropical high from the north Atlantic to the North American landmass dominates during boreal winter (December to February), as do the strong easterly trades found on its equator ward flank. Coupled with a strong trade inversion, a cold ocean and reduced atmospheric humidity, the region is generally at its driest during this period. With the onset of boreal spring, however, the NASH moves offshore, and the easterly trade wind intensity decreases with its convergence with the Southern Hemisphere winds in the ETPac. Especially for Central America, the variation in the strength of the trade winds is an important determinant of climate throughout the year. There is also a high and weak trade inversion: the ocean warms and atmospheric moisture is abundant (Hidalgo, Durán-Quesada, Amador, \& Alfaro, 2015). Besides the NASH, other significant synoptic influences include: (a) the influence of the Inter Tropical Convergence Zone (ITCZ) (Hidalgo et al., 2015; QuirósBadilla \& Hidalgo-León, 2016) and its seasonal migration - mainly affecting the Pacific side of southern Central America; (b) the intrusions of polar fronts of mid-latitude origin (called "Nortes" in Spanish) which modify the dry winter and early summer climates of the entire 


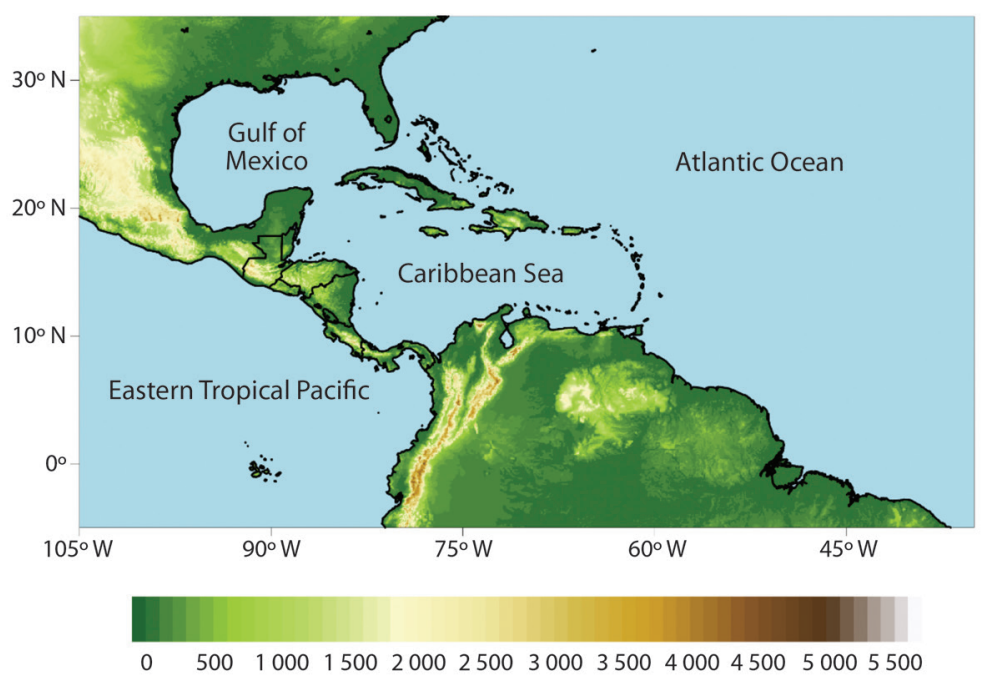

Fig. 1. The Intra-Americas Sea region as defined by Amador (2008). The terrain elevation is represented by the color-scale.

Caribbean and Central American region; (c) westward propagating tropical disturbances - a summer season feature associated with much rainfall especially over the Caribbean region (Amador et al., 2006; Amador, Rivera, et al., 2016); (d) the Western Hemisphere Warm Pool (WHWP) (Wang \& Enfield, 2001, 2003; Wang \& Fiedler, 2006); (e) the Caribbean low-level jet (CLLJ) (Amador, 1998, 2008; Maldonado, Rutgersson, Amador, Alfaro, \& Claremar, 2016) and its interaction with the ITCZ (Hidalgo et al., 2015) and (f) the midsummer drought (MSD) (Magaña, Amador, \& Medina, 1999; Karnauskas, Seager, Giannini, \& Busalacchi, 2013; Herrera, Magaña, \& Caetano, 2015; Maldonado, Rutgersson, Alfaro, Amador, \& Claremar, 2016). These elements depict the general frame of the regional climate and variability in the region (Wang, Lee, \& Enfield, 2008), and form part of the vast variety of regional climate components present in this area. Even with the above identified influences, many of the dynamical and physical mechanisms and interactions with the regional climate are still not fully understood (Amador, 2008).

As it will be seen in the following sections, at inter-annual time-scales the most dominant influence to moisture in the region is the
El Niño/Southern Oscillation (ENSO) variations (Hidalgo, Alfaro, \& Quesada-Montano, 2017), while other climatic phenomena from the Pacific and Atlantic influence precipitation at inter-annual and lower frequencies (Alfaro, 2007c; Maldonado, Alfaro, Fallas-López, \& Alvarado, 2013; Amador, Durán-Quesada, et al., 2016; Maldonado, Alfaro, Rutgersson, \& Amador, 2016; Maldonado, Rutgersson, Alfaro et al., 2016).

Wind field: The trade winds are the lowlevel tropospheric flow, typically known as the Hadley Cells. The Hadley Cell is part of the equator-ward branch transporting large amounts of moisture, producing an area of uplift (convergence) that destabilizes the stratification at low latitudes. They are responsible for the convective activity and associated precipitation distribution that take place near or within the ITCZ. At local scales, the interaction with the topography helps to explain the temporal and spatial rainfall variability in some areas of Central America (Amador, Chacón, $\&$ Laporte, 2003). Two subtropical high-pressure systems located near $30^{\circ} \mathrm{N}$, in both the Pacific Ocean (the North Pacific high) and in the NASH, produce (in average) a relative 
strong meridional pressure gradient between the subtropics and tropics, which accelerates the air masses towards the equator, generating the trade winds.

Monsoonal systems such as the North American Monsoon System (NAMS) and the South American Monsoon System (SAMS) interact in different ways with the trade winds, and are important mechanisms that explain the precipitation during the warm season in the ETPac. Vera et al. (2006) reviewed both systems in more detail. According to Amador et al. (2006), the most relevant monsoon system for ocean-atmosphere dynamics in the ETPac is the NAMS. The NAMS is generated due to the seasonal thermal contrast that occurs in this season over the ETPac and the entire American continent (e.g. Higgins et al., 2003). The NAMS has been shown to be associated with the summer time precipitation of the ETPac (Higgins, Yao, \& Wang, 1997; Mock, 1996).

At regional scales, during the boreal summer, more complex circulations than those in winter develop in the IAS region. Low-level flows occur during the boreal summer, particularly the Gulf of California low-level jet (Douglas, 1995; Douglas, Valdez-Manzanilla, \& García-Cueto, 1998), the Chocó low-level jet (CJ, Poveda \& Mesa, 2000), and the CLLJ (Amador, 1998, 2008). The second mechanism is developed by the CJ in the western coast of Colombia near $5^{\circ} \mathrm{N}$. It reaches its maximum by October-November, then decreases its intensity until it becomes almost absent during the period of February to March. Low-level warm air and moisture convergence associated with the $\mathrm{CJ}$ and low surface pressure and orographic vertical motion on the western Andes contribute to deep convective activity, which is organized as meso-scale convective complexes (Poveda \& Mesa, 2000). Durán-Quesada, Gimeno, Amador, \& Nieto (2010) have pointed out the association between the $\mathrm{CJ}$ and the moisture input from the Pacific Ocean to Central America.

The third low-level flow, the CLLJ, peaks in winter and summer (Amador, 1998, 2008; Amador et al., 2003; Maldonado, Rutgersson, Amador, et al., 2016). The mean annual cycle of the CLLJ index at $925 \mathrm{hPa}$ is shown in Fig. 2. During summer, it is barotropically unstable, and has potential interaction with transients, such as easterly waves. It has been associated with precipitation in the Pacific slope of Central America (Hidalgo et al., 2015, 2017). From May to July, easterly waves lose energy and momentum strengthening the mean current and causing the low-level jet to peak in July. The CLLJ is an important element to explain the convective activity during July through November, and contributes to the understanding of the climate of the region. CLLJ has been found as the most important mechanism for moisture transport from the Caribbean Sea to Central America (DuránQuesada et al., 2010; Gimeno et al., 2012). In winter, however, its formation is distinct to the

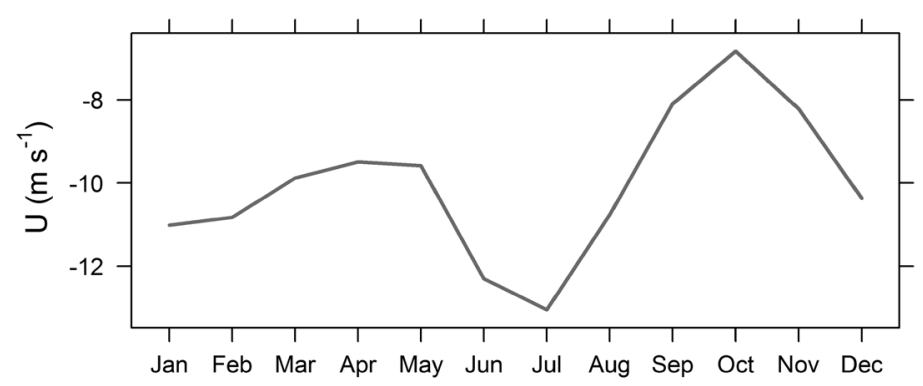

Fig. 2. Annual cycle of the Caribbean low-level jet (CLLJ) index as defined by Amador (2008). The CLLJ index is estimated using the area average of the zonal wind at $925 \mathrm{hPa}$ for the region $12.5^{\circ} \mathrm{N}-17.5^{\circ} \mathrm{N}$ and $70^{\circ} \mathrm{W}-80^{\circ} \mathrm{W}$. The climatology is calculated using the monthly values from ERA-Interim reanalysis products for the time period 1979-2014. The horizontal resolution is $0.75^{\circ}$ latitude by longitude. 
summer component (Amador, 2008; Cook \& Vizy, 2010; Wang, 2007).

During the northern hemisphere winter, the ITCZ is at its southernmost position (Srinivasan \& Smith, 1996), and SSTs over the adjacent areas of the Caribbean and the Pacific are relatively uniform, with values usually below $28{ }^{\circ} \mathrm{C}$ (Amador et al., 2003). The trade winds are also intensified and a frequent southward displacement of air masses occurs. From December - March, cold air masses coming from Canada and the Polar Regions penetrate deep into the tropics and produce strong winds associated with intense periods of rainfall (Schultz et al., 1997; Schultz, Bracken, \& Bosart, 1998; Zárate-Hernández, 2013).

Interaction with topography (i.e. wind is funneled through topographical gaps in southern Mexico and Central America), and a strong gradient in the sea level pressure (SLP) between the basins (a low in the Pacific and a high in the Caribbean) due to the intrusion of cold outbreaks, produce strong near-surface wind events that can extend far into the ETPac (Brenes et al., 2003; Amador et al., 2006; Alfaro \& Cortés, 2012). High SLP over the southwestern Caribbean generates northerly surface winds across the Isthmus of Panama that extend offshore from the Gulf of Panama into the ETPac region (Amador et al., 2006). During this season, these intense winds over the Caribbean are associated with the winter branch of the CLLJ (Amador, 2008; Maldonado, Rutgersson, Amador, et al., 2016), and its interaction with the mountains forces rainfall in Central America.

According to Amador et al. (2006) and Amador, Rivera, et al. (2016), the wind stress curl has a strong seasonal cycle with a marked meridional migration of the up-welling (positive curl) and down-welling (negative curl) areas that is mostly associated with the southeast and northeast trade patterns and its northsouth migration in the ETPac. The distribution of this variable is almost zonal, and most of the large-scale features are located north of the equator. In general, the fluctuations in the magnitude of the wind stress curl in the tropics are mainly related to seasonal atmospheric circulation and the ITCZ.

Moisture transport: Durán-Quesada et al. (2010) identified two main moisture sources for Central America. The first one and the most important is the Caribbean Sea. The second appears near the equatorial Pacific region. These results were highlighted also by Gimeno et al. (2012) who indicated that the major amount of humidity in the continental part of Central America originates from the nearby oceans. A third continental source of moisture was found by Durán-Quesada (2012) over Venezuela due to the water recycling processes.

The intensity and extent of the moisture sources vary throughout the year. The Caribbean source (CS) does not vary significantly along the year, except by a slight displacement towards the Gulf of Mexico during winter. In contrast, the Pacific source (PS) shows significant variation throughout the year, and disappears as a source during winter and spring, mainly due to the influence of the ITCZ (Durán-Quesada et al., 2010). Seasonally, during the boreal summer, the humidity transport from the CS is more effective and contributes to precipitation in Central America, while the moisture that departs from PS is not even able to reach the entire Central American region, contributing to precipitation only in its southernmost portion, specifically in Costa Rica. Through the boreal winter, there is a reduction in the moisture transport, consistent with the precipitation pattern over Central America. The latter results in dry conditions (mainly in the Pacific basin) during this season. Moisture convergence in Central America during winter is clearly less important than during spring (March, April, May) and autumn (September, October, November), when the moisture flux over the continental area becomes more relevant.

To understand the role of the CLLJ for moisture transport, it is worth mentioning that the CLLJ acts not only as a moisture belt, but also as a humidity collector that is capable of modulating surface evaporation as a result of 
its moisture content (Wang, Lee, \& Enfield, 2007). Many studies found that the core of the CLLJ is consistent with the maximum nucleus of moisture gain over the Caribbean Sea (Wang, 2007; Wang \& Lee, 2007; Wang et al., 2007; Durán-Quesada et al., 2010). The major contribution occurs during boreal summer, and for the case of the CS region, coincides with the maximum observed winds in the core of the CLLJ. However, the second maximum moisture source of the CLLJ in boreal winter is not associated with any important transport, mainly due to the incidence of the dry season. The dry season is characterized by less intense jet winds than in summer and a minimal amount of precipitable water.

Durán-Quesada et al. (2010) highlighted that the contribution of moisture to Central America that originates in the PS region is partly determined by the presence of the CJ, which in turn allows the development of deep convection in the region. This contribution is more noticeable over northern Colombia when it appears to be combined with the effect of orographic lifting, as described by Poveda \& Mesa (2000). The importance of the PS region is greatest during those parts of the boreal summer and autumn that coincide with the maximum velocities within the core of the CJ. A significant part of the moisture transported by this jet is unable to reach Central America completely, due to the loss of moisture in the
ITCZ and the presence of a mountain range in Costa Rica.

According to Durán-Quesada, Gimeno, \& Amador (2017), inter-annual variability of precipitation is highly dependent on the low-level jets with the atmospheric variability modes. Evaporative sources show opposite anomaly patterns during warm and cold ENSO phases, as a result of the strengthening and weakening, respectively, of the CLLJ during the summer months. Trends in both moisture supply and precipitation over the last three decades suggest that precipitation trends are not homogeneous for Central America. Trends in moisture supply from the CS and PS show a marked north-south seesaw, with an increasing supply from the CS Sea to northern Central America. Long-term trends in moisture supply show increases during the transition months (March and October).

Precipitation: The NASH produces strong easterly trades winds towards the equator: this is the dominant wind regime in Central America. The interaction between the trades and the topography, plus the location of the isthmus, imprint the regional features of the climate and weather. This interaction produces two regional climates (Fig. 3) - Pacific and Caribbean (Taylor \& Alfaro, 2005; Amador et al., 2006). Nonetheless, the complex orography is capable of producing local climate and weather patterns, noted mainly in the high variability

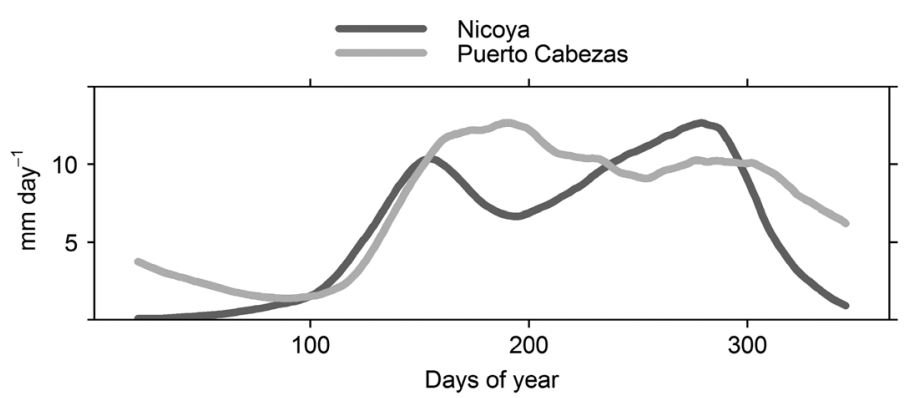

Fig. 3. Annual cycle of precipitation time series filtered with a triangular window of 31 days as in Soley (1994). The blue line shows the annual cycle of precipitation of the Nicoya station located on the Pacific side of Costa Rica, while the pink line shows the annual cycle of rainfall for Puerto Cabezas station in the Caribbean side of Nicaragua. The climatology is calculated for the period 1969-2010 from daily precipitation data. The data was provided by the respective National Meteorological Services. 
observed in precipitation with respect to the altitude (Fernández, Chacón, \& Melgarejo, 1996; Amador et al., 2003).

The Pacific side presents a bimodal rainfall distribution around the year (Fig. 3, Alfaro, 2002). A first maximum occurs in May-June, partly because of the northern migration of the ITCZ. However, the migration of the ITCZ neither explains the generalized deep convection during the rainy season over the whole region since the ITCZ is not found at latitudes $10^{\circ}-12^{\circ} \mathrm{N}$ (Alfaro, 2000; Maldonado, Alfaro et al., 2016), nor explain the beginning and the ending of the rainy spells. Additionally, to this migration, the SST of the neighboring seas have warmed reaching about $29{ }^{\circ} \mathrm{C}$ and deep convection activity is developed along with a sub-tropical lower-tropospheric cyclonic circulation anomaly over the subtropics.

A relative minimum of precipitation through July-August in the Pacific is caused by the MSD (Magaña et al., 1999; Karnauskas et al., 2013; Herrera et al., 2015; Maldonado, Rutgersson, Alfaro et al., 2016). During the occurrence of the MSD in these months, the convective activity diminishes. Due to a decrease of about $1{ }^{\circ} \mathrm{C}$ in the SST over the ETPac, the associated cyclonic circulation anomaly weakens, resulting in an acceleration of the low-level flow that crosses the isthmus. This leads to a formation of divergence anomalies that inhibit deep convection activity, and the strengthening of the easterlies, forcing upward motion and intense precipitation over the Caribbean side and subsidence and clear skies upon the Pacific slope (Hidalgo et al., 2015). The second maximum peaks during August through October due to the presence of fewer deep clouds, which would produce an increment of incoming solar radiation increasing the SST above $28^{\circ} \mathrm{C}$. Then, this warming in the SST produces an increase of evaporation from the oceans to the atmosphere; in addition, weakened trade winds and a low-level convergence anomaly lead to enhanced deep convection. Normally, this season presents the highest frequency of extreme events over the Pacific slope (Alfaro et al., 2010; Maldonado et al., 2013).
On the Caribbean side, rainfall decreases during these months, due to a decrease in the strength of the trade winds (Taylor \& Alfaro, 2005; Amador et al., 2006). The Caribbean side shows a different rainfall mode (Fig. 3), as pointed out by Taylor \& Alfaro (2005). Precipitation during the winter months, along this coast, is mostly related to humidity convergence, mid-latitude air intrusions (Schultz et al., 1997, 1998), and less frequent low-level cloud systems traveling from the east (Velásquez, 2000).

Hurricanes: Taylor \& Alfaro (2005) describe that tropical storms and hurricanes are seasonally common in the northern Caribbean and Gulf of Mexico. These phenomena deserve brief discussion due to the significant loss of life, the extensive infrastructural damage, and the disruption to the Central American and Caribbean economies and way of life that occur with hurricane landfall or even relative close approximations (Amador, 2011; Pérez-Briceño et al., 2016). On average, eight hurricanes will pass near or through the Caribbean region in a year, but this number can vary significantly from year to year. Global climatic phenomena, such as ENSO, seem to play a role in determining the number of storms which will develop and pass through the Caribbean. During the warm ENSO phase, an apparent decrease occurs in the frequency of tropical storms due to an increase in wind shear over the Caribbean during the hurricane season (Alfaro, 2007a). Goldenberg, Landsea, Mestas-Nuñez, \& Gray (2001) show evidence of decadal variation in storm activity with some decades on average being less active (1970s to 1990 s) than others (1920s to 1960s). The hurricane season runs from June to November with a peak in September (Alfaro \& Quesada, 2010; Alfaro et al., 2010). The ETPac is itself an important region of hurricane development affecting mainly the Pacific coast of Mexico, and occasionally the northern part of Central America (Guatemala and El Salvador) (Amador, Hidalgo, Amador et al., 2012; Farfán, Alfaro, \& Cavazos, 2013). 
Alfaro (2007a); Alfaro \& Quesada (2010) and Alfaro et al. (2010) studied the variability in the annual number of tropical cyclones (TC) for the Atlantic as a function of the inter-annual and decadal variability of SST. Given a scenario below normal, neutral and above normal in some selected SST indices for 1944-2004 (61 years), a contingency table analysis was used to calculate the conditional probabilities for scenarios below normal and neutral and above normal for different annual time series of TCs activity in the Atlantic basin. This annual activity was conditioned on the difference between the normalized SST of the Tropical North Atlantic (TNA) and the Equatorial Eastern Pacific. Lower than average activity years were observed with cooler (warmer) than average temperatures in the TNA (Eastern Equatorial Pacific), greater wind shear over the TNA but smaller over the ETPac, near Central America; and higher (lower) SLP in the TNA (Eastern Equatorial Pacific). Higher than average activity years were observed in general terms with opposite anomaly patterns in the regions described previously.

\section{Climate variability elements in the Intra-Americas Sea Large scale modulators}

El Niño/Southern Oscillation (ENSO): ENSO is a two-component physical mechanism that describes the coupling of SST anomalies in the tropical Pacific Ocean and the fluctuation in tropical SLP gradient in the Western and Eastern Pacific Hemispheres, also known as the Southern Oscillation. El Niño is associated with unusual strong warming events that occur every two to seven years and goes hand in hand with the basin-scale tropical Pacific anomalies (Wang \& Fiedler, 2006). ENSO variability in the ETPac is centered along the equator, but is closely related to variability of the tropical WHWP. Authors such as Chen \& Taylor (2002) and Bell \& Chelliah (2006) suggest that ENSO forces variations in the SST field and vertical wind shear that trigger the inter-annual variability of the hurricane season during ENSO events. Moreover, direct teleconnection (not necessarily related to changes in hurricane frequencies) has been established in several studies that suggest an increase (decrease) of precipitation (especially in the Pacific slope of Central America) associated with cold (warm) ENSO phases (Dai \& Wigley, 2000; Giannini, Cane, \& Kushnir, 2001; Cid-Serrano, Ramírez, Alfaro \& Enfield, 2015; Hidalgo et al., 2017; Maldonado, Rutgersson, Amador, et al., 2016; Sánchez-Murillo, Durán-Quesada, Birkel, Esquivel-Hernández, \& Boll, 2016).

The Atlantic Multi-Decadal Oscillation (AMO): AMO is a 70 year period mode in SST (Delworth \& Mann, 2000; Enfield, MestasNuñez, \& Trimble, 2001). This signal has also been found in different modeling analysis (Delworth, Manabe, \& Stouffer, 1993; Delworth \& Greatbatch, 2000; Latif et al., 2004), and it was detected as the first rotated empirical orthogonal functions with a large response in the North Atlantic SST (Mestas-Nuñez \& Enfield, 2001). The AMO signal modulates precipitation variations in different regions such as the IAS (Giannini, Kushnir, \& Cane, 2000; Enfield et al., 2001). Wetter (drier) conditions over Central America (north-east Brazil) during JJA (DJF) were found by Zhang \& Delworth (2006). AMO has also played a significant role in modulating the impact of ENSO on droughts. The connection between AMO and other regional features such as the Atlantic Warm Pool (AWP) has also been studied. Wang et al. (2008) showed that warm (cool) phases of the AMO are associated with repeated large (small) AWPs, suggesting the relationship between the AMO and Atlantic TCs. The latter agrees with results that indicate the presence of multi-decadal variations in hurricane activity due to the Atlantic SST (Goldenberg et al., 2001). AMO is then of importance related to the low frequency variability of precipitation as it modulates the distribution of moisture and extreme rainfall events (Maldonado et al., 2013, Maldonado, Alfaro et al. 2016; Maldonado, Rutgersson, Alfaro et al. 2016). 
The Pacific Decadal Oscillation (PDO): The Pacific Decadal Oscillation (PDO) is a long-lived El Niño-like pattern of the variability of the Pacific climate (Zhang, Wallace, \& Battisti, 1997). Mantua, Hare, Zhang, Wallace, \& Francis (1997) highlight the PDO as the dominant pattern of Pacific Decadal Variability. Even when the PDO is referred to as an El Niño-like pattern, it differs from ENSO in the time scale of the persistence of events, and its fingerprint is more noticeable in the extratropics rather than the tropics (Mantua \& Hare, 2002). The pattern of a warm PDO phase is featured by cooler than normal SSTs in the central North Pacific and warmer than normal SSTs along the west coast of the Americas. Symmetry in SST anomalies patterns between northern and southern hemispheres exhibited by the PDO has been noted by Evans et al. (2001). The mechanisms of the PDO are complex and are still an open issue; however, some studies suggest the importance of the tropical coupling for the existence of the PDO (Feng, Wu, Lin, \& Meng, 2010). Schneider \& Cornuelle (2005) propose the PDO evolves from a composition between the forces due to Niño 3.4, and the changes of the Aleutian low (inter-annual frequencies) and the Kuroshio-Oyashio Extension (decadal time scales). The importance that the PDO may have for global climate is related to a correlation between the PDO index (Mantua et al., 1997) and precipitation anomalies in Central America.

Mantua et al. (1997) founded that the warm PDO phases are associated with anomalously dry periods in the eastern coasts of Eurasia, Northwest Pacific of USA, Central America and northern South America. The same phase also seems to be related to the wetter than normal conditions in the Gulf of Alaska, Southwest USA and Mexico, South-east Brazil, South central South America and Western Australia. Fallas-López \& Alfaro (2012a, b) and Maldonado, Rutgersson, Amador, et al. (2016) founded that during winter the PDO forces are more appreciable in combination with the El Niño phases. The PDO intensifies El Niño signal in SLP and precipitation anomalies, if both processes have the same phase. The PDO, however, modulates precipitation mainly over Mexico and southern parts of the USA.

The North Atlantic Oscillation (NAO): Greatbatch (2000) made a detailed revision of the NAO. It is the most important variability mode in the North Atlantic Ocean. One way to define and index for NAO is through the difference between normalized mean winter (December to March) SLP anomalies at Lisbon, Portugal and Stykkisholmur, Iceland (Hurrell, 1996). NAO is an element of the Arctic Oscillation pattern, NAO is linked with SST anomalies in the East/South-east of Greenland.

NAO has been also associated with the strengthening of the NASH and the North-Eastern trade winds, affecting thus the circulation in the IAS. Therefore, the impact of the NAO is associated with climate features over the IAS, SST in the TNA, the size of the WHWP and the CLLJ. Seasonal variations of the NAO may be reflected in its influence on the IAS easterly winds and precipitation patterns (Wang, 2007; Fallas-López \& Alfaro, 2012a; Maldonado, Rutgersson, Amador, et al., 2016). Malmgren, Winter, \& Chen (1998) found that during the boreal summer, the NAO index has an inverse relation with the observed precipitation patterns over Puerto Rico.

\section{Regional-scale modulators}

Regional circulation systems: Two important regional circulation systems modulate the weather and climate in the region. The first mechanism is the CLLJ over the Caribbean Sea, and the second is the CJ. The CLLJ is important for moisture transport in the region, and to explain the convective activity during the summer months. During winter, it has a second maximum; nonetheless, it has shown no relation with convection during this season (Amador, 1998, 2008). The CJ peaks in October-November, and contributes to the moisture transport for the southernmost part of Central America (Durán-Quesada et al., 2010). Furthermore, the CJ is associated with deep 
convection activity over the western Andes region in Colombia (Poveda \& Mesa, 2000).

SST of Neighboring Oceans: The influence of the SST anomalies on the precipitation variability field has been widely studied (Enfield \& Alfaro, 1999; Alfaro, 2000, 2007b; Wang \& Enfield, 2001, 2003; Wang et al., 2007, 2008; Wang \& Lee, 2007; Maldonado et al., 2013; Maldonado, Alfaro et al., 2016; Maldonado, Rutgersson, Alfaro et al., 2016). The beginning and ending of the rain spells are related to fluctuations in the SST of the Atlantic and Pacific Oceans (e.g. Alfaro, Cid \& Enfield, 1998). SST anomalies are also associated with the magnitude of rainfall and frequency of rainy days (Maldonado \& Alfaro, 2010, 2011; Maldonado et al., 2013). Amador et al. (2006) pointed out that the seasonal cycle of SST is important in defining key climatological features, especially during summer-autumn, such as the WHWP development (Wang \& Enfield, 2001; Wang \& Fiedler, 2006), the appearance of MSD (Magaña et al., 1999; Karnauskas et al., 2013; Herrera et al., 2015; Maldonado, Rutgersson, Alfaro, et al., 2016) and favorable areas for cyclogenesis (Goldenberg et al., 2001). During the northern winter, SST isotherms over the Caribbean and the ETPac are mostly zonally distributed, with values usually below $28-29^{\circ} \mathrm{C}$, except in the central ETPac, and to the west of Central America, where there is a maximum of SST throughout the year. As result of this SST distribution, there is a relatively strong vertical trade wind shear, along with a reduction in evaporation. These conditions do not allow major convective activity to occur in most of the Pacific slope of Central America during this season. In addition, the ITCZ is at its southernmost position (Srinivasan \& Smith, 1996) during the boreal winter.

In boreal summer, the WHWP dominates the SST distribution over most of the ETPac region (Magaña et al., 1999; Wang \& Enfield, 2001, 2003). Variations in surface variables (precipitation and temperature) in different sectors of Mesoamerica, including its west coast, are the result of a combination of fluctuations in the equatorial tropical Pacific and in the TNA (Amador et al., 2006). Studies such as Alfaro, Cid, \& Enfield (1998), Alfaro \& Cid (1999a, 1999b) and Enfield \& Alfaro (1999) show that the strongest rainfall signal occurs when TNA and tropical Pacific SST anomalies are in a configuration of meridional dipole (anti-symmetric) across the ITCZ, that is, when these anomalies have an opposite sign. The rainy season in south Central America tends to start early and end late in years that begin with warm SST in the TNA. Ending dates are also delayed when the ETPac is cold.

\section{Local-scale modulators}

Topography is the main local modulator of the variability in the region. Fernández et al. (1996) explored the variability of rainfall with altitude in Central America by examining the vertical rainfall distribution in Costa Rica along a topographic profile which crossed the country from the Pacific to the Caribbean coasts. The mountain profile, with highest peak of approximately $3000 \mathrm{~m}$, is oriented perpendicular to the prevailing large-scale north-easterly trade winds. Their analysis of rainfall amounts and the seasonal and diurnal variations at 14 raingauge stations located on or close to the topographic profile reveals considerable variation with altitude. Maximum rainfall on both the windward (Caribbean) and leeward (Pacific) sides of the main mountain range occur at intermediate altitudes rather than on the mountain tops. (See also the work of Chacón \& Fernandez, 1985). Average yearly maxima of 7735 $\mathrm{mm}$ on the windward side and $6692 \mathrm{~mm}$ on the leeward side were observed at about $2000 \mathrm{~m}$ and $800 \mathrm{~m}$ respectively. According to Amador et al. (2006), changes in the intensity of the trade winds in the Caribbean Sea and the Gulf of Mexico exert an important control on precipitation by means of wind-topography interactions. Boreal winter cold fronts descending from extra-tropical latitudes generate strong low- level wind jets throughout the Tehuantepec, Papagayo and Panama Gulf passages. 
Interaction between the terrains with the induced flow coming from the Pacific ITCZ, due to some prevailing synoptic system, produces a type of disturbance that contributes to precipitation in Central America, which is named the "temporales" (Hastenrath, 1991; Fernández et al., 1996). These are periods of weak-moderate nearly continuous rain, lasting several days and affecting a relatively large region. Their definition includes the condition that the wind must be weak; however, Amador et al. (2003) have shown that in some cases winds can be intense and long-lasting. Fernández et al. (1996) identify at least four synoptic configurations that can eventually generate conditions for a temporal: (1) deep lower and middle troposphere troughs in the easterlies (hurricanes excluded), (2) intrusions of an upper troposphere troughs in mid-latitude westerlies, (3) outbreaks of cold air from North America (Zárate-Hernández, 2013; 2014), and (4) the direct and indirect effect of hurricanes. Velásquez (2000) also found that westwardtraveling, low-level cloud systems (Peña \& Douglas, 2002) over the Caribbean reaching the Pacific, which are not necessarily associated with mid-latitude cold air intrusions can also generate conditions for a temporal. The frequency of these events presents a great deal of inter-annual and intra-seasonal variability, and their relationship to ENSO or to other large-scale climatic signals is still unclear (Amador et al., 2006).

Sea-breeze circulations are relevant regional modulators of the climate, on islands and peninsulas, since they favor the development of convective systems. These circulations are marked by a diurnal cycle due to the thermal contrast between the coastline and sea. They can be associated to a diurnal cycle of precipitation. However, in coastal regions with nearby complex topography, like Central America, the induced flow can impact the temporal and spatial distribution of the meso-scale features in rainfall. Besides that, there is evidence in regions with similar characteristics to the Central American isthmus (i.e. West coast of Colombia), that the sea breeze can penetrate over near-coastal mountains into a valley approximately $100 \mathrm{~km}$ away (Mapes et al., 2003).

Historical and projected climate/weather hazard in Central America: Alvarado \& Alfaro (2003) studied the TC frequency in the Caribbean Sea that affected Costa Rica during the 20th century. None of the 125 cyclones passed over Costa Rica, and the closest tracked was the 1993 tropical storm Bret. The 1988, category 5 , hurricane Gilbert was the most intense; however, the hurricane Joan during the same year is considered the cyclone with the most severe damage over Costa Rica. Hurricane Mitch in 1998 is catalogued as the cyclone with more damages in Central America and with more rain accumulated by topographic effects. The 40s (80s) was the decade with more (less) hurricane events. The modulation of this aspect could be the combination of inter-annual and inter-decadal variability in the ETPac and TNA. It is concluded that the intensity of a temporal in Costa Rica is not directly associated with cyclone's magnitude, because it depends also on the relative cyclone's position and its velocity over the Caribbean Sea. Tropical storm landing in the southern part of Central America are rare. Few cases are found in recorded history: Díaz-Bolaños (2004) reported a tropical storm landing in the northern part of Costa Rica in 1887, and Hurricane Martha landed near Panama in between November 21-25th in 1969 (Solano, Alfaro \& Quesada, 2011). In November 24th, 2016 hurricane Otto landed over Costa Rica, and was the first recorded case of a land-falling hurricane over the country (Brown, 2017).

Alfaro \& Pérez-Briceño (2014) examined the impacts of cold fronts or outbreaks, easterly waves and TCs that originated in the surrounded seas of Central America. They found that impacts associated with cold fronts (tropical cyclones) were located mainly in the Costa Rican Caribbean (Pacific) slope, while those associated with easterly waves have a more even spatial distribution through the country. Pérez-Briceño et al. (2016) found that extreme hydro-meteorological events in 
Central America are common, and the impacts usually occur in areas where natural and social variables result in emergency situations. In their 2016 study, they analyzed the temporal distribution of impacts associated with occurrence of three types of meteorological events: TCs, easterly waves and cold fronts. The study showed that towns with the greatest populations of each country, like capitals: Ciudad de Guatemala (Guatemala), Distrito Central (Honduras), San Salvador (El Salvador), Managua (Nicaragua), San Jose (Costa Rica), Ciudad de Panama (Panama) have high correlation with impact occurrences. They concluded that in this kind of analysis, it is necessary to consider socioeconomic variables like poverty, health and Human Development Index, to infer robust conclusions about impact causes.

Amador, Alfaro, Rivera, \& Calderón (2010) used indexes of the CLLJ, Niño 3, TNA, AMO, and Outgoing Long-Wave Radiation (OLR) as quantified for the period 1950-2007, to study their relationship with TC frequency for summer-autumn of the Northern Hemisphere. A remarkable inverse relationship is found between both, the strength of the wind speed at $925 \mathrm{hPa}$ and the vertical wind shear at low levels, and the monthly relative frequency of TCs for two selected areas in the Caribbean. The July peak in wind speed and lowlevel vertical wind shear are associated with a minimum in the monthly relative frequency of TCs. On the contrary, a decrease in the wind speed and vertical shears are associated with a maximum value of the relative frequency of TCs. Stronger (weaker) than normal CLLJ summer winds (July-August) during warm (cold) ENSO events imply a stronger (weaker) than normal vertical wind shear at low-levels in the Caribbean. This condition may inhibit (allow) deep convection, disfavoring (favoring) TC development during these months. Correlation values of the monthly mean CLLJ core winds and the monthly normalized values of TNA - Niño 3 index for 1950-2007 showed statistical significance greater than $99 \%$ during July-August. During El Niño years, low-level wind increases at the jet core, strengthening the low-level convergence near Central America at the jet exit and the low-level divergence in the central Caribbean at the jet entrance. The descending motion associated with the latter acts as an inhibiting factor for convection and TC development.

TC activity in the Caribbean is not only sensitive to ENSO influences, but to the strength of the CLLJ vertical wind shear, to the barotropic energy conversions induced by the lateral wind shear, to the intensity of the regional scale descending motion associated with the jet entrance, and to the SST cooling generated by the CLLJ at the sea surface. Climatology of a group of General Circulation Models (GCMs) used in the 2007 report of the IPCC were tested to study their ability to capture the low-level wind annual cycle over the Caribbean and the known CLLJ structure (Amador et al., 2010; Hidalgo et al., 2015). Some models do not capture basic characteristics of the jet. A discussion of cyclone potential over the Caribbean, based on the relationships developed using the model's climatology, is presented for the period 2010-2050.

Current state of seasonal climate forecast systems: As Maldonado et al. (2013) explain, Central American National Meteorological and Hydrological Services (NMHS) have periodic Regional Climate Outlook Fora (RCOF) to elaborate seasonal predictions. Since 1997, Regional Climate Outlook Forums (RCOFs) have taken place in various Latin American countries, to produce seasonal prediction products (International Research Institute for Climate and Society [IRI], 2001). They have been funded by several international agencies with the assistance of local and regional entities such as the Regional Committee of Hydraulic Resources (CRRH) in Central America (Donoso \& Ramírez, 2001; GarcíaSolera \& Ramírez, 2012).

Alfaro, Soley, \& Enfield (2003) and Alfaro, Hidalgo, Mora, Pérez-Briceño, \& Fallas (2016) add that generally, these forums gather representatives of the Meteorological and Hydrological services, as well as members of 
the scientific and academic community, who work on the elaboration of regional and local climate forecasts for the next 1-2 seasons. The objective of these forums is to use national climatic experience to elaborate a regional consensus for the climate outlook. In Central America, precipitation is the variable generally forecasted for the months following the forum. The forecast is presented in a format that is useful for the agencies involved. The recommended methodology for the forecast is quite simple, and this forecast is later integrated geographically with the coordinated inputs from the countries of the region, and is used as a tool for the meteorological services and as a basis for expected impact scenarios for stakeholders and decision-makers.

Alfaro et al. (2003) and Alfaro, Hidalgo, Mora et al. (2016) mentioned also that scientific and academic communities have discussed certain problems that arise during the development of the forums and how the research results can be better used to improve the forums' products. One of the problems identified during the RCOFs is that because there is not a standardized methodology for producing the forecast, the contributions from different countries can result in a disjointed regional forecast that is sometimes physically inconsistent across political borders. Moreover, it appears that the statistics behind the tools used are not familiar to some of the participants, such that the national climate forecasts are sometimes based only on subjective evaluations. Some of the roots of these problems have been identified: i) the resources of some institutions are limited to the routine tasks, and only a small portion of their budget is allocated for research and capacity building; and ii) there have been very few opportunities for training on the concepts required for the RCOFs.

A total of 41 RCOFs maps were assessed in a recent work of Alfaro, Hidalgo, Mora et al. (2016). For that purpose, 156 rain gauge stations, along with 689 and 17158 grid points from TRMM and CHIRPS data sets were used, respectively. Seasonal total rainfall stations were compared also with three other outlooks:
Climate Predictability Tool outputs, previous RCOF month conditions persistence and one predicting always neutral conditions. Their results showed that RCOFs maps have an aggregate value to decision-makers, because they have skillful information most of the times. Outlooks based on an Always Neutral forecast had the worse median skill results for all cases, meaning that decisions taken without considering climate outlook information is worse than those taken in account the RCOF maps. Additionally, the inclusion of objective tools with a more specific given weight in the consensus map production, could increase the RCOFs skill.

Precipitation: the precipitation in Central America shows different relationships with the tropical Atlantic and Pacific oceans in the inter-annual and decadal scales (Alfaro, 2002). In the inter-annual scale, the wettest (driest) years in the region were dominated in general by warmer (colder) SST in the tropical Atlantic compared with the ETPac. While in the decadal scale, the precipitation shows positive correlations with both tropical ocean regions.

Alfaro $(2007 \mathrm{c})$ used a statistical model based on Canonical Correlation Analysis (CCA) to explore the predictability of early May, June, July (MJJ) and late August, September, October (ASO) rainfall seasons in Central America. Explanatory variables are seasonal Atlantic and Pacific Ocean SST for the region inside $112.5^{\circ} \mathrm{E}-7.5^{\circ} \mathrm{W}$ and $7.5^{\circ} \mathrm{S}-62.5^{\circ} \mathrm{N}$ during 1958-1998. For the early rainfall season, MJJ, positive (negative) tropical Atlantic SST anomalies were associated with positive (negative) rainfall anomalies over a broad area located at the north of the studied region. For the late season, ASO, opposite sign anomalies in the Atlantic and Pacific oceans that surround Central America were associated with a strong rainfall signal, in which positive \& negative (negative \& positive) SST anomalies in the Pacific \& Atlantic Tropical oceans, tend to be associated with lobes of negative (positive) rainfall anomalies mainly at Central American Pacific slope. The model results were cross 
validated, showing significant skill values over an important portion of the studied region.

Fallas-López \& Alfaro (2012a) used the statistical technique of contingency table analysis to produce predictive schemes associated with rainfall in Central America. As a first step, principal component analysis was used to produce indices using 146 daily station records. Two rainfall components were obtained associated with Central America Pacific and Caribbean slopes. The objective to support the Regional Climate Outlook Forums utilized the predictive schemes which used the trimesters of May-June-July, August- September-October and the 4-month period of December-JanuaryFebruary-March as targets for predictions in rainfall. Different climate indices were used as predictors, associated with several climate variability sources that influence the climate patterns in Central America, and using one or two bimonthlies before the predicted season. Useful predictive schemes were found for practically all the relationships mentioned previously, noting that most of the Central America climate variability could be explained by the El Niño (La Niña) (e.g. inter-annual variability) and the Atlantic (AMO, mainly, e.g. multidecadal variability) indices. This categorical seasonal prediction tool was extended recently by Cid-Serrano et al. (2015) and Ramírez, Cid, \& Alfaro (2015).

In addition, Fallas-López \& Alfaro (2012b) elaborated a seasonal climate prediction for Central America based on CCA. SSTs from the oceans around the isthmus were used as predictors. Precipitation was used as a predictand field, using 146 meteorological stations located in Mesoamerica with monthly records from 1971 to 2000 . The SST area used was $60^{\circ}$ $\mathrm{N}-60^{\circ} \mathrm{S}$ and $270^{\circ}-0^{\circ} \mathrm{W}$. In general, the SST associated with previous trimester was used for every predicted season. The CCA showed the best precipitation results for ASO, which is the trimester associated with the season of maximum precipitation over the Central American Pacific slope. Some of the modes identified in the analysis display spatial patterns associated with known climate variability sources as
ENSO, meaning that CCA is useful for seasonal prediction in Central America and for predictor patterns explanation and possible associated climate indices. Results showed that CCA use in Central America can also help in the RCOF tasks, providing objective analysis for the predictive relationships found in the region.

Recently, as is explained in Maldonado et al. (2013), after RCOF, meetings with different socioeconomic stakeholders took place to translate the probable climate impacts from predictions. From the feedback processes of these meetings has emerged that extreme event and rainy days' seasonal predictions are necessary for different sectors. As is shown in their work, these predictions can be tailored using CCA for rain during ASO, showing that extreme events and rainy days in Central America are influenced by inter-annual variability related to ENSO and decadal variability are associated mainly with AMO.

Maldonado \& Alfaro (2010, 2011) generated models based on CCA for prediction of extreme precipitation events during ASO, using as predictor the SST. The skill is due to the hydrological response of the SST anomalies over the isthmus as predictor, and as predictands: the accumulated monthly rainfall, days with precipitation, the percentage of days exceeding the 80th percentile (extreme wet) and the percentage of days that do not exceed the 10th percentile (dry extreme). It was found that using the July SST results in a relationship between ENSO and AMO events with the occurrence of precipitation extremes for ASO. Maldonado, Rutgersson, Alfaro et al. (2016) have also implemented a similar approach using CCA to study the MSD intensity and magnitude and their association with SST anomalies. They found that the SST contrast between the Pacific and Caribbean waters is the most important variability mode controlling the MSD intensity and magnitude at inter-annual scales. In addition, Maldonado, Alfaro et al. (2016) found, using CCA, that for the early rainy season the SST anomalies over the TNA region are the most relevant variability mode 
explaining total and extreme precipitation, and frequency of rainy days during May-June.

Temperature: Alfaro (2000) used 337 grid points $\left(0.5^{\circ}\right.$ latitude $\times 0.5^{\circ}$ longitude $)$, over Central America, from a monthly air surface temperature data set to adjust multiple regression models between the temperature first principal components (dependent variables) and several SST indices (independent variables) for all the seasons. These models show that indices related with ENSO have the main influence over the region when compared with the influence of the other indices, having positive correlation with all the surface temperature seasons. It could be an indicative of latent and sensible heat transfer from the ocean to the overlying atmosphere. All these models had percentage of detection greater than $50 \%$ and false alarm rates lower than $10 \%$. In the decadal scale, the temperature in Central America shows similar relationships with the tropical Atlantic and Pacific oceans through positive correlations with both oceanic regions.

Hidalgo et al. (2017) produced a highresolution grid $(5 \mathrm{~km})$ monthly average temperature data-set over Central America from 1970 to 1999 . The data were used along with an existing precipitation data-set to study variability in the region. Consistently with other studies, it was found that annual precipitation trends in Central America are generally statistically non-significant, while significant temperature trends are generalized in the region. Most of the significant temperature trends are positive, but some regions in Honduras and Panama experienced cooling trends. At interannual time-scales, precipitation in large part of the region (and more strongly in the Pacific slope) is strongly correlated with ENSO and the CLLJ, while temperature variations are strongly correlated to ENSO and Tropical Atlantic SST variations.

Alfaro \& Lizano (2001) explored the influence of the surrounding tropical oceans on the Central American Pacific coast, using a Transfer Function Model which was fixed to SST anomalies of the Gulf of Tehuantepec,
Papagayo, Panama and Quepos time series. As independent variables, the following were used: Niño 3.4, Tropical North and South Atlantic indices. These models show that Niño 3.4 has the most important influence over the region when compared with the influence of the other indices, having positive correlation with all the SST anomalies series. It shows an influence of this index on the relative thermocline's depth in front of the Central American Pacific Coast.

Alfaro (2007b) used a model based on CCA to explore climate associations in surface temperature in Central America and the MarchMay predictability. This trimester allocates the maximum according to the annual cycle, using as predictor field SST in the Atlantic and Pacific oceans, from 1958 to 1998 (41 years). The stronger relationship was found with Niño 3 , noticing that positive (negative) East equatorial pacific SST anomalies are associated with positive (negative) air surface temperature over almost all the Central American isthmus.

Climate change projections: Results of the projected climate in the 2050-2099 period showed median significant reductions in precipitation (as much as 5-10\%) and runoff (as much as 10-30 \%) in northern Central America. Therefore, in this sub-region the prevalence of severe drought may increase significantly in the future under a moderate emissions scenario (Hidalgo, Amador, Alfaro, \& Quesada, 2013). Similar results were confirmed by Hidalgo, Alfaro, \& Quesada-Montano (2017), who found not only that the northern part of the regions would be drier at mid-century, but also that the southern part would be wetter. This was explained by the authors by a projected southern displacement of the ITCZ.

According to Hidalgo \& Alfaro (2012), the most consistent result is that the current north-south socio-economic contrast between the countries (in which the southern countries of Panama and Costa Rica present better living conditions than the rest of the Central American countries), is not diminished in the future; in fact, for some climate and social-condition 
scenarios this contrast is exacerbated in the future. Moreover, Panama and Costa Rica are the only countries that present improved living conditions at the end of the century when considering the positive effect of the increases in gross domestic product (GDP) and the negative effects of climate change. It is worrisome that the north-south differences in the living standards will keep growing in the region, and therefore attention should be given to the socioeconomic and physical aspects that may play a role in increasing these differences (Hidalgo \& Alfaro, 2012).

Future challenges: Rivera \& Amador (2008) measured the ability of two GCMs (ECHAM4.5 and CCM3.6) to simulate key climate features of Central America which is determined by the evaluation of both precipitation and low-level wind fields for the period 1990-1999. According to the evaluation, ECHAM4.5 exhibits a more realistic representation of the regional climate. Therefore, its output is used to provide the initial and boundary conditions necessary to perform a dynamical downscaling using the regional model MM5v3.

Rivera \& Amador (2009) determined that GCM ECHAM4.5 shows more ability than CCM3.6 to simulate key climate features of Central America. For such reason, output from ECHAM4.5 was used to perform a dynamical downscaling experiment using the MM5v3 model, in which a set of high-resolution simulations (of up to $30-\mathrm{km}$ horizontal resolution) was generated for January 2000. The results of the dynamical downscaling allowed the conclusion that MM5v3 can suitably reproduce aspects of the Central American climate that GCMs cannot capture because of their coarse horizontal resolution, their limitations in representing both the regional topography and the meso-scale dynamical interactions. Comparison with data derived from observations indicates that the MM5v3 simulates the region of maximum low-level wind that is related to the CLLJ, although the regional model underestimates its intensity. Regarding the precipitation patterns, they agree with those derived from the observations (drier areas in the Pacific, wetter areas in the Caribbean). Nevertheless, there is a generalized overestimation in the amount of simulated rain. The analysis of the standard deviation for a twelve-member sample shows areas in which MM5v3 has greater dispersion or uncertainty (mainly to the south of Panama).

Additionally, Alfaro (2014) used seven daily gauge stations records, located at two important river basins of Costa Rica, Tarcoles and Tempisque, to study and to characterize the MSD from 1937 to 2012. Among the aspects considered are the MSD Start, Timing, End, Duration, Intensity and Magnitude. The modulation and seasonal predictability of these aspects by climate variability sources as Equatorial Eastern Pacific was lately explored, showing that warmer (cooler) conditions in Niño 3.4 tend to be associated to drier (wetter) MSD events. Maldonado, Rutgersson, Alfaro et al. (2016) found that in addition to El Niño conditions, MSD intensity and magnitude are also modulated by the inter-oceanic temperature gradient between the Pacific and Atlantic Oceans, which makes this variability mode the most important. Maldonado, Rutgersson, Alfaro et al. (2016) found that CCA shows potential predictability of the MSD intensity and magnitude using SST with leading times of up to three months. Using CCA as a diagnostic tool, it is found that during June, an SST dipole pattern upon the neighboring waters to Central America is the main variability mode controlling the inter-annual variability of the MSD features. However, there is also evidence that the regional waters are playing an important role in the annual modulation of the MSD features. The waters in the PDO vicinity might be also controlling the rainfall during the MSD, while exerting an opposite effect at the north and south regions of Central America.

Alfaro, Hidalgo, \& Mora (2016) used 162 gauge stations to build skillful CCA prediction models for May-June (MJ) season as the first peak of the rainy season, using as predictands monthly rainfall accumulations and Standardized Precipitation Index (SPI) values over 
Central America. SST anomalies were used as predictors handling a domain bounded by $63^{\circ}$ $\mathrm{N}-10^{\circ} \mathrm{S}$ and $152^{\circ} \mathrm{E}-15^{\circ} \mathrm{W}$, along with the Palmer Drought Severity Index (PDSI) values covering the isthmus. Leading times from December to April were explored in the predictor fields. CCA models, using February's SST anomalies and April's PDSI showed significant skill values for the prediction of MJ accumulations and the Standard Precipitation Index (SPI) over an important portion of Central America. Models' loadings showed that warmer (cooler) Eastern equatorial SST anomalies in the Pacific along with cooler (warmer) SST anomalies in the TNA during February, tend to be related with drier (wetter) conditions in almost all the isthmus during the next MJ season. It is suggested that SST mode could modulate MJ precipitation in Central America influencing the position of the ITCZ and the strength of the trade winds. Additionally, it was observed that drier (wetter) soil moisture (PDSI) in April tends to be related with drier (wetter) precipitation conditions in almost all the isthmus during next MJ period. The prediction of the MJ precipitation as the first peak of the rainy season is important in the Central American isthmus, because wetter (drier) MJ seasons tend to be associated with early (late) onsets of the rainy season on the Pacific slope. Having a late start of the rains, followed by a drier season in MJ in conjunction with a deep MSD, would affect significantly key socioeconomic sectors in the isthmus like hydro-power generation, water supply for human consumption (as main cities in the isthmus are located on the Pacific slope) and agriculture.

In that sense, Maldonado, Alfaro et al. (2016) showed that the SST over TNA controls the MJ precipitation fluctuations at inter-annual scales, due to its connection with the tropical upper tropospheric trough. Warmer (colder) temperatures generate SLP below normal in the Caribbean region, associated with an increase in the heights at $200 \mathrm{hPa}$. This vertical configuration reduces the wind shear between 850 and $200 \mathrm{hPa}$ and increases the input of humidity to mid-levels, creating favorable conditions for deep convection and favoring the generation of TC activity. In the Pacific, a positive anomalous low-level moisture flux is observed from the ocean to the continental parts of the region and may enhance the formation of meso-scale systems. The classic prediction schemes show a lead time of one or two months; this is an operational advantage for climate services. The atmospheric model outcomes replicate the main results found in the composite analysis, reflecting its potential use for Model Output Statistics predictive schemes.

Amador \& Alfaro (2014) make an analysis of some of the atmospheric systems (easterly waves, cold fronts and TC) hitting Central America, to estimate their effects on socioeconomic activities and potential impacts on World Heritage Sites (WHS) during the period 2002-2012. The second objective is to identify, for a case study, the potential effects of hydro-meteorological events associated with a tropical storm on the Diquis Delta region in southern Costa Rica. This site, an important unique archaeological site of stone spheres, has been proposed by this country as a WHS. To achieve both, public data bases like HURDAT (North Atlantic Hurricane Database), and information from regional newspapers and National Emergency Committees, among other sources, were used for the study of socio-economic impacts caused by these natural hazards.

To accomplish the latter, course resolution NCEP/NCAR (National Center for Environmental Prediction / National Center for Atmospheric Research) Reanalysis atmospheric data served to initialize MM5v3. This approach permitted obtainment of higher resolution grid data for a set of atmospheric variables for a case study associated with the formation of tropical storm Alma upon the Pacific basin. The MM5v3 resulted winds and precipitation, among other variables, were then used to evaluate potential impacts on the WHS region. Among the systems analyzed for Central America, TCs were the ones that most severely impacted regional social life and worsened the already weak regional economies. During the period analyzed, TCs affected regions where 
WHS are very relevant to cultural life and touristic income. The MM5 derived data shows its potential for providing detailed space and time atmospheric data to help quantify and anticipate impacts for WHS protection and management. The overall results are expected to bring to the attention of organizations and governments the importance of socio-economic and cultural losses associated with the impacts caused by natural hazards near WHS in the region.

Conclusions: In this paper, we examined the main climate forces and climate modulators in Central America and their connection with natural disaster and climate change. Furthermore, we reviewed the current climate forecast systems implemented in the region. Below we summarize the main findings from the literature:

El Niño/Southern Oscillation is the main climate modulator; however, other indices, such as TNA, AMO and PDO have shown a relevant association with precipitation anomalies and extreme rainfall events during different season. In addition, regional SSTs have revealed significant association with precipitation fluctuations at inter-annual and seasonal scales.

The assessment of natural threats (with hydro-meteorological origin) and climate change impact on Central America society needs the addition of socio-economic variables to fully understand such phenomena and their impacts.

Forecast systems in Central America have been improved in the recent years. CCA is the most utilized technique at seasonal scales, since CCA can be used not only as a diagnostic tool of the atmospheric conditions, but also as a forecast technique similar to simple linear regression.

The regional model MM5v3 shows its potential for providing detailed space and time atmospheric data to help quantify and anticipate impacts for WHS protection and management. We, therefore, hope to have provided a congruent overview that will attract the attention of organizations and governments to the socio-economic and human impact of hydrometeorological extremes in the WHS region.

\section{ACKNOWLEDGMENTS}

This research was carried out within the Centre for Natural Disaster Science research school, supported by the Swedish International Development Cooperation Agency through their contract with the International Science Programme at Uppsala University (contract number: 54100006). The authors would like to thank the following UCR projects: 805-B6-143 (supported by CONICIT/MICITT \& Research Council/UCR), 805-B4-227, 805-A9-532, 805A4-906 (PESCTMA/UCR). Agregar, 805-B7286, (UCREA) y cambiar 805-B6-143 por 805-B6-143 \& 805-B7-507.

\section{RESUMEN}

Una revisión de los principales controladores y de la variabilidad del clima en América Central y sistemas de pronóstico estacional: América Central es una región susceptible a desastres naturales y cambio climático. En el presente estudio, se revisaron los principales forzantes atmosféricos y oceánicos, así como los moduladores del clima que afectan la región, en diferentes escalas espaciales y temporales. Además, se revisó la asociación entre variabilidad climática con amenazas naturales, así como aspectos de cambio climático (pasado y futuro) en la región. Adicionalmente, se revisaron el estado actual de los sistemas de predicción estacional usados en América Central. A escalas de tiempo interanuales, El Niño/Oscilación del Sur es el principal modulador del clima en la región, sin embargo, otros índices climáticos como el Atlántico Tropical Norte, la Oscilación Multidecadal del Atlántico y la Oscilación Decadal del Pacífico han mostrado una asociación significativa con las anomalías de precipitación en el área. Mientras que la temporada de huracanes se relaciona con eventos extremos de precipitación. Los sistemas de predicción estacional actuales en la región han mostrado un desarrollo sostenido, incluyendo reducción de escala dinámica como estadística, incrementando la predictibilidad en variables como precipitación. Sin embargo, varios estudios han reportado la necesidad de incluir, además de la información climática, variables socio-económicas para evaluar el impacto de desastres naturales y cambio climático en la región, lo cual, ha llamado la atención de organizaciones y gobiernos sobre la importancia de pérdidas de vidas humanas y socio-económicas asociadas con los impactos causados por amenazas naturales. 
Palabras clave: Amenazas naturales, predicción estacional climática, variabilidad climática, cambio climático.

\section{REFERENCES}

Alfaro, E. J. (2000). Eventos cálidos y fríos en el Atlántico Tropical Norte. Atmósfera, 13(2), 109-119.

Alfaro, E. J. (2002). Some Characteristics of the Annual Precipitation Cycle in Central America and their Relationships with its Surrounding Tropical Oceans. Tópicos Meteorológicos y Oceanográficos, 9(2), 88-103.

Alfaro, E. J. (2007a). Escenarios climáticos para temporadas con alto y bajo número de huracanes en el Atlántico. Revista de Climatología, 7, 1-13.

Alfaro, E. J. (2007b). Predicción Climática de la Temperatura Superficial del Aire en Centroamérica. Ambientico, 165, 6-10.

Alfaro, E. J. (2007c). Uso del análisis de correlación canónica para la predicción de la precipitación pluvial en Centroamérica. Ingeniería y Competitividad, 9(2), $33-48$.

Alfaro, E. J. (2014). Caracterización del "veranillo" en dos cuencas de la vertiente del Pacífico de Costa Rica, América Central (Characterization of the Mid Summer Drought in two Pacific slope river basins of Costa Rica, Central America). Revista de Biologia Tropical, 62(4), 1-15.

Alfaro, E. J., \& Cid, L. (1999a). Ajuste de un modelo VARMA para los campos de anomalías de precipitación en Centroamérica y los índices de los océanos Pacífico y Atlántico Tropical. Atmósfera, 13 (12), 205-222.

Alfaro, E. J., \& Cid, L. (1999b). Análisis de las Anomalías en el inicio y el término de la estación lluviosa en Centroamérica y su relación con los océanos Pacífico y Atlántico Tropical. Tópicos Meteorológicos y Oceanográficos, 6(1), 1-13.

Alfaro, E. J., \& Cortés, J. (2012). Atmospheric forcing of cool subsurface water events in Bahía Culebra, Gulf of Papagayo, Costa Rica. Revista de Biología Tropical, 60, 173-186.

Alfaro, E. J., \& Lizano, O. (2001). Algunas relaciones entre las zonas de surgencia del Pacífico Centroamericano y los Océanos Pacífico y Atlántico Tropical. Revista de Biologia Tropical, 49(2), 185-193.

Alfaro, E. J., \& Pérez-Briceño, P. M. (2014). Análisis del impacto de fenómenos meteorológicos en Costa Rica, América Central, originados en los mares circundantes. Revista de Climatología, 14, 1-11.
Alfaro, E. J., \& Quesada, A. (2010). Ocurrencia de ciclones tropicales en el Mar Caribe y sus impactos sobre Centroamérica. Revista Intersedes, 11(22), 136-153.

Alfaro, E. J., Cid, L., \& Enfield, D. B. (1998). Relaciones entre la precipitación en Centroamérica y los Océanos Pacífico y Atlántico Tropical. Investigaciones Marinas, 26, 59-69.

Alfaro, E. J., Hidalgo, H., \& Mora, N. (2016). Prediction of MJ rainfall season using CCA models. Tópicos Meteorológicos y Oceanográficos, 15(2), 5-19.

Alfaro, E. J., Hidalgo, H., Mora, N., Pérez-Briceño, P., \& Fallas, B. (2016). Assessment of Central America Regional Climate Outlook Forum maps, 1998-2013. Tópicos Meteorológicos y Oceanográficos, 15(1), 37-52.

Alfaro, E. J., Quesada, A., \& Solano-Chaves, F. J. (2010). Análisis del Impacto en Costa Rica de los Ciclones Tropicales ocurridos en el Mar Caribe desde 1968 al 2007. Diálogos Revista Electrónica, 11(2), 22-38.

Alfaro, E. J., Soley, J., \& Enfield, D. (2003). Uso de una Tabla de Contingencia para Aplicaciones Climáticas (Use of a Contingency Table for Climatic Applications). Guayaquil, Ecuador: ESPOL and FUNDESPOL.

Alvarado, L., \& Alfaro, E. J. (2003). Frecuencia de los ciclones tropicales que afectaron a Costa Rica durante el siglo XX. Tópicos Meteorológico y Oceanográficos, 10(1), 1-11.

Amador, J. A. (1998). A Climatic Feature of the Tropical Americas: The Trade Wind Easterly Jet. Tópicos Meterológicos y Oceanográficos, 5(2), 91-102.

Amador, J. A. (2008). The Intra-Americas Sea Low-level Jet Overview and Future Research. Annals of the New York Academy of Sciences, 1146(1), 153-188.

Amador, J. A. (2011). Socio-economic impacts associated with meteorological systems and tropical cyclones in Central America in 2010. (In: State of the Climate 2011). Bulletin of American Meteorological Society, 92(6), S184.

Amador, J. A., \& Alfaro, E. J. (2014). Weather and climate socio-economic impacts in Central America for the management and protection of world heritage sites and the Diquis Delta culture in Costa Rica (a case study). Advances in Geosciences, 35, 157-167.

Amador, J. A., Chacón, R. E., \& Laporte, S. (2003). Climate and climate variability in the Arenal river basin of Costa Rica. Climate and water: transboundary challenges in the Americas. Kluwer, Dordrecht, 317-349.

Amador, J. A., Alfaro, E. J., Lizano, O. G., \& Magaña, V. O. (2006). Atmospheric forcing of the eastern tropical Pacific: A review. Progress in Oceanography, 69(24), 101-142. 
Amador, J. A., Alfaro, E. J., Rivera, E. R., \& Calderón, B. (2010). Climatic features and their relationship with tropical cyclones over the Intra-Americas seas. In Hurricanes and Climate Change (pp. 149-173). Springer Netherlands.

Amador, J. A., Alfaro E. J., Calderón, B., Durán-Quesada, A. M., Hidalgo H. G, \& Rivera, I. L. (2012). Regional Climates: Central America and the Caribbean. (In: State of the Climate 2012). Bulletin of American Meteorological Society, 94(8), S154-S155.

Amador, J. A., Durán-Quesada, A. M., Rivera, E. R., Mora, G., Sáenz, F., Calderón, B., \& Mora, N. (2016). The easternmost tropical Pacific. Part II: Seasonal and intraseasonal modes of atmospheric variability. Revista de Biología Tropical, 64(1), S23-S57.

Amador, J. A., Rivera, E. R., Durán-Quesada, A. M., Mora, G., Sáenz, F., Calderón, B., \& Mora, N. (2016). The easternmost tropical Pacific. Part I: A climate review. Revista de Biología Tropical, 64(1), S1-S22.

Bell, G. D., \& Chelliah, M. (2006). Leading Tropical Modes Associated with Interannual and Multidecadal Fluctuations in North Atlantic Hurricane Activity. Journal of Climate, 19(4), 590-612.

Brenes, C. L., Coen, J. E., Chelton, D. B., Enfield, D. B., León, S., \& Ballestero, D. (2003). Wind driven upwelling in the Gulf of Nicoya, Costa Rica, 24(5), 1127-1133.

Brown, D. P. (2017). Hurricane Otto (AL162016, EP22016): 20-26 November 2016. Natl. Hurricane Center, Tropical Cyclone Rep.

Cid-Serrano, L., Ramírez, S. M., Alfaro, E. J., \& Enfield, D. B. (2015). Analysis of the Latin American west coast rainfall predictability using an ENSO index. Atmósfera, 28(3), 191-203.

Chacón, R. E., \& Fernandez, W. (1985). Temporal and spatial rainfall variability in the mountainous region of the reventazón river basin, Costa Rica. Journal of Climatology, 5(2), 175-188.

Chen, A. A., \& Taylor, M. A. (2002). Investigating the link between early season Caribbean rainfall and the El Niño +1 year. International Journal of Climatology, 22(1), 87-106.

Cook, K. H., \& Vizy, E. K. (2010). Hydrodynamics of the Caribbean Low-Level Jet and its relationship to precipitation. Journal of Climate, 23(6), 1477-1494.

Dai, A., \& Wigley, T. M. L. (2000). Global patterns of ENSO-induced precipitation. Geophysical Research Letters, 27(9), 1283-1286.

Delworth, T. L., \& Greatbatch, R. J. (2000). Multidecadal thermohaline circulation variability driven by atmospheric surface flux forcing. Journal of Climate, 13(9), $1481-1495$
Delworth, T. L., \& Mann, M. E. (2000). Observed and simulated multidecadal variability in the Northern Hemisphere. Climate Dynamics, 16(9), 661-676.

Delworth, T., Manabe, S., \& Stouffer, R. J. (1993). Interdecadal Variations of the thermohaline circulation in a coupled Ocean-Atmosphere model. Journal of Climate, 6(11), 1993-2011.

Diaz-Bolaños, R. E. (2004). La tormenta tropical de 1887 $\mathrm{y}$ su paso por las fuentes históricas costarricenses. Estudios, 18-19, 39-56.

Donoso, M., \& Ramírez, P. (2001). Latin America and the Caribbean: Report on the climate outlook forums for mesoamerica. In International Research Institute for Climate Prediction (Ed.). Coping with the climate: A step forward, Workshop Report: A multi-stakeholder review of Regional Climate Outlook Forums 16-20 October 2000 (pp. 16-20). Pretoria, South Africa: IRI Publication IRI-CW/01/1.

Douglas, M. W. (1995). The Summertime Low-Level Jet over the Gulf of California. Monthly Weather Review, 123(8), 2334-2347.

Douglas, M. W., Valdez-Manzanilla, A., \& Garcia Cueto, R. (1998). Diurnal Variation and Horizontal Extent of the Low-Level Jet over the Northern Gulf of California. Monthly Weather Review, 126(7), 2017-2025.

Durán-Quesada, A. M. (2012). Sources of moisture for Central America and transport based on a Lagrangian approach: variability, contributions to precipitation and transport mechanisms (Doctoral dissertation). Vigo: Spain: Universidade de Vigo.

Durán-Quesada, A. M., Gimeno, L., \& Amador, J. (2017). Role of moisture transport for Central American precipitation. Earth System Dynamics, 8, 147-161.

Durán-Quesada, A. M., Gimeno, L., Amador, J. A., \& Nieto, R. (2010). Moisture sources for Central America: Identification of moisture sources using a Lagrangian analysis technique. Journal of Geophysical Research: Atmospheres, 115(D5), D05103.

Enfield, D. B., \& Alfaro, E. J. (1999). The Dependence of Caribbean Rainfall on the Interaction of the Tropical Atlantic and Pacific Oceans. Journal of Climate, 12(7), 2093-2103.

Enfield, D. B., Mestas-Nuñez, A. M., \& Trimble, P. J. (2001). The Atlantic Multidecadal Oscillation and its relation to rainfall and river flows in the continental U.S. Geophysical Research Letters, 28(10), 2077-2080.

Evans, M. N., Cane, M. A., Schrag, D. P., Kaplan, A., Linsley, B. K., Villalba, R., \& Wellington, G. M. (2001). Support for tropically-driven Pacific decadal variability based on paleoproxy evidence. Geophysical Research Letters, 28(19), 3689-3692. 
Fallas-López, B., \& Alfaro, E. J. (2012a). Uso de herramientas estadísticas para la predicción estacional del campo de precipitación en América Central como apoyo a los Foros Climáticos Regionales. 1: Análisis de tablas de contingencia. Revista de Climatología, 12, 61-79.

Fallas-López, B., \& Alfaro, E. J. (2012b). Uso de herramientas estadísticas para la predicción estacional del campo de precipitación en América Central como apoyo a los Foros Climáticos Regionales. 2: Análisis de Correlación Canónica. Revista de Climatología, 12, 93-105.

Farfán, L. M., Alfaro, E. J., \& Cavazos, T. (2013). Characteristics of tropical cyclones making landfall on the Pacific coast of Mexico: 1970-2010. Atmósfera, 26(2), 163-182.

Feng, L., Wu, D., Lin, X., \& Meng, X. (2010). The effect of regional ocean-atmosphere coupling on the longterm variability in the Pacific Ocean. Advances in Atmospheric Sciences, 27(2), 393-402.

Fernández, W., Chacón, R., \& Melgarejo, J. W. (1996). On the rainfall distribution with altitude over Costa Rica. Revista Geofisica, 44, 57-72.

Fiedler, P. C., \& Lavín, M. F. (2006). Introduction: A review of eastern tropical Pacific oceanography. Progress in Oceanography, 69(2-4), 94-100.

García-Solera, I., \& Ramírez, P. (2012). Central America’s Seasonal Climate Outlook Forum. Retrieved from http://www.climate-services.org/wp-content/ uploads/2015/09/CRRH_Case_Study.pdf.

Giannini, A., Cane, M. A., \& Kushnir, Y. (2001). Interdecadal changes in the ENSO teleconnection to the Caribbean Region and the North Atlantic Oscillation. Journal of Climate, 14(13), 2867-2879.

Giannini, A., Kushnir, Y., \& Cane, M. A. (2000). Interannual variability of Caribbean rainfall, ENSO, and the Atlantic Ocean. Journal of Climate, 13(2), 297-311.

Gimeno, L., Stohl, A., Trigo, R. M., Dominguez, F., Yoshimura, K., Yu, L., ... Nieto, R. (2012). Oceanic and terrestrial sources of continental precipitation. Reviews of Geophysics, 50(4), RG4003.

Goldenberg, S. B., Landsea, C. W., Mestas-Nuñez, A. M., \& Gray, W. M. (2001). The recent increase in Atlantic hurricane activity: Causes and Implications. Science, 293(5529), 474-479.

Greatbatch, R. J. (2000). The North Atlantic Oscillation. Stochastic Environmental Research and Risk Assessment, 14(4-5), 213-242.

Hastenrath, S. (1991). Climate Dynamics of the Tropics. Dordrecht, Netherlands: Springer.
Herrera, E., Magaña, V., \& Caetano, E. (2015). Air-sea interactions and dynamical processes associated with the midsummer drought. International Journal of Climatology, 35(7), 1569-1578.

Hidalgo, H. G., \& Alfaro, E. J. (2012). Some physical and socio-economic aspects of climate change in Central America. Progress in Physical Geography, 36(3), 379-399.

Hidalgo, H., Alfaro, E. J., \& Quesada-Montano, B. (2017). Observed (1970-1999) climate variability in Central America using a high-resolution meteorological dataset with implication to climate change studies. Climatic Change, 141, 13-28.

Hidalgo, H. G., Amador, J. A., Alfaro, E. J., \& Quesada, B. (2013). Hydrological climate change projections for Central America. Journal of Hydrology, 495, 94-112.

Hidalgo, H. G., Durán-Quesada, A. M., Amador, J. A., \& Alfaro, E. J. (2015). The Caribbean Low-Level Jet, the Inter-Tropical Convergence Zone and Precipitation Patterns in the Intra-Americas Sea: A Proposed Dynamical Mechanism. Geografiska Annaler: Series A, Physical Geography, 97(1), 41-59.

Higgins, R. W., Yao, Y., \& Wang, X. L. (1997). Influence of the North American Monsoon System on the U.S. Summer Precipitation Regime. Journal of Climate, 10(10), 2600-2622.

Higgins, R. W., Douglas, A., Hahmann, A., Berbery, E. H., Gutzler, D., Shuttleworth, J., ... Zhang, C. (2003). Progress in Pan American CLIVAR Research: The North American Monsoon System. Atmósfera, 16(1).

Hurrell, J. W. (1996). Influence of variations in extratropical wintertime teleconnections on northern hemisphere temperature. Geophysical Research Letters, 23(6), 665-668.

International Research Institute for Climate and Society (2001). Latin America Regional Report. In Coping with the climate: A step Forward. Workshop Report "A multi-stakeholder review of Regional Climate Outlook Forums" (pp. 136-138). Pretoria, South Africa.

Karnauskas, K. B. B., Seager, R., Giannini, A., \& Busalacchi, A. J. J. (2013). A simple mechanism for the climatological midsummer drought along the Pacific coast of Central America. Atmósfera, 26(2), 261-281.

Latif, M., Roeckner, E., Botzet, M., Esch, M., Haak, H., Hagemann, S., ... Mitchell, J. (2004). Reconstructing, Monitoring, and Predicting Multidecadal-Scale Changes in the North Atlantic Thermohaline Circulation with Sea Surface Temperature. Journal of Climate, 17(7), 1605-1614.

Magaña, V., Amador, J. A., \& Medina, S. (1999). The midsummer drought over Mexico and Central America. Journal of Climate, 12(6), 1577-1588. 
Maldonado, T., \& Alfaro, E. J. (2010). Propuesta metodológica para la predicción climática estacional de eventos extremos y días con precipitación. Estudio de caso: Sur de América Central. InterSedes, 11(21), $182-214$

Maldonado, T., \& Alfaro, E. J. (2011). Predicción estacional para ASO de eventos extremos y días con precipitación sobre las vertientes Pacífico y Caribe de América Central, utilizando análisis de correlación canónica. InterSedes, 12(24), 78-108.

Maldonado, T., Alfaro, E. J., Fallas-López, B., \& Alvarado, L. (2013). Seasonal prediction of extreme precipitation events and frequency of rainy days over Costa Rica, Central America, using Canonical Correlation Analysis. Advances in Geosciences, 33, 41-52.

Maldonado, T., Alfaro, E. J., Rutgersson, A., \& Amador, J. A. (2016). The early rainy season in Central America: the role of the tropical North Atlantic SSTs. International Journal of Climatology. https://doi. org/10.1002/joc.4958

Maldonado, T., Rutgersson, A., Alfaro, E. J., Amador, J. A., \& Claremar, B. (2016). Interannual variability of the midsummer drought in Central America and the connection with sea surface temperatures. Advances in Geosciences, 42, 35-50.

Maldonado, T., Rutgersson, A., Amador, J. A., Alfaro, E. J., \& Claremar, B. (2016). Variability of the Caribbean low-level jet during boreal winter: large-scale forcings. International Journal of Climatology, 36(4), 1954-1969.

Malmgren, B. A., Winter, A., \& Chen, D. (1998). El NiñoSouthern Oscillation and North Atlantic Oscillation Control of Climate in Puerto Rico. Journal of Climate, 11(10), 2713-2717.

Mantua, N. J., \& Hare, S. R. (2002). The Pacific Decadal Oscillation. Journal of Oceanography, 58(1), 35-44.

Mantua, N. J., Hare, S. R., Zhang, Y., Wallace, J. M., \& Francis, R. C. (1997). A Pacific Interdecadal Climate Oscillation with Impacts on Salmon Production. Bulletin of the American Meteorological Society, 78(6), 1069-1079.

Mapes, B. E., Warner, T. T., Xu, M., Negri, A. J., Mapes, B. E., \& Xu, M. (2003). Diurnal Patterns of Rainfall in Northwestern South America. Part II: Model Simulations. Monthly Weather Review, 131(5), 799-812.

Mestas-Nuñez, A. M., \& Enfield, D. B. (2001). Eastern Equatorial Pacific SST Variability: ENSO and NonENSO Components and Their Climatic Associations. Journal of Climate, 14(3), 391-402.

Mock, C. J. (1996). Climatic controls and spatial variations of precipitation in the western United States. Journal of Climate, 9(5), 1111-1125.
Muñoz, A. G., Ruiz-Carrascal, D., Ramírez, P., León, G., Quintana, J., Bonilla, A., ... Sánchez, O. (2012). Risk Management at the Latin American Observatory. In N. Banaitiene (Ed.). Risk Management-Current Issues and Challenges (pp. 533-556). Rijeka, Croatia: InTech. doi: 10.5772/50788.

Neri, C., \& Magaña, V. (2016). Estimation of Vulnerability and Risk to Meteorological Drought in Mexico. Weather, Climate, and Society, 8(2), 95-110.

Oficina de las Naciones Unidas para la Reducción del Riesgo de Desastres \& Centro de Coordinación para la Prevención de los Desastres Naturales en América Central (2014). Informe regional del estado de la vulnerabilidad y riesgos de desastres en Centroamérica. Panamá, Panamá: UNISDR/CEPREDENAC.

Peña, M., \& Douglas, M. W. (2002). Characteristics of Wet and Dry Spells over the Pacific Side of Central America during the Rainy Season. Monthly Weather Review, 130(12), 3054-3073.

Pérez-Briceño, P. M., Alfaro, E. J., Hidalgo, H., \& Jiménez, F. (2016). Distribución espacial de impactos de eventos hidrometeorológicos en América Central. Revista de Climatología, 16, 63-75.

Poveda, G., \& Mesa, O. J. (2000). On the existence of Lloró (the rainiest locality on Earth): Enhanced ocean-land-atmosphere interaction by a low-level jet. Geophysical Ressearch Letters, 27(11), 1675-1678.

Quirós-Badilla, E., \& Hidalgo-León, H. G. (2016). Variabilidad y conexiones climáticas de la zona de convergencia intertropical del Pacífico este. Topicos Meteorologicos y Oceanograficos, 15(1), 21-36.

Ramírez, S., Cid, L., \& Alfaro, E. J. (2015). Modelos lineales generalizados para la predicción de precipitaciones en el Valle Central de Costa Rica, América Central usando ENOS: una propuesta metodológica. Revista Geofisica, 65, 11-27.

Retana, J. A. (2012). Eventos hidrometeorológicos extremos lluviosos en Costa Rica desde la perspectiva de la adaptación al cambio en el clima. Ambientales, 44, 5-16.

Rivera, E. R., \& Amador, J. A. (2008). Predicción Estacional del Clima en Centroamérica mediante la reducción de escala dinámica. Parte I: Evaluación de los Modelos de Circulación General CCM3.6 y ECHAM4.5. Revista de Matemática: Teoría y Aplicaciones, 15(2), 131-173.

Rivera, E. R., \& Amador, J. A. (2009). Predicción estacional del clima en Centroamérica mediante la reducción de escala dinámica. Parte II: aplicación del modelo MM5V3. Revista de Matemática: Teoría y Aplicaciones $C N-0000,16(1), 76-104$.

Sánchez-Murillo, R., Durán-Quesada, A. M., Birkel, C., Esquivel-Hernández, G., \& Boll, J. (2017). Tropical 
precipitation anomalies and d-excess evolution during El Niño 2014-16. Hydrological Processes, 31(4), 956-967.

Schneider, N., \& Cornuelle, B. D. (2005). The Forcing of the Pacific decadal oscillation. Journal of Climate, 18(21), 4355-4373.

Schultz, D. M., Bracken, W. E., \& Bosart, L. F. (1998). Planetary- and Synoptic-Scale Signatures Associated with Central American Cold Surges. Monthly Weather Review, 126(1), 5-27.

Schultz, D. M., Bracken, W. E., Bosart, L. F., Hakim, G. J., Bedrick, M. A., Dickinson, M. J., \& Tyle, K. R. (1997). The 1993 Superstorm Cold Surge: Frontal Structure, Gap Flow, and Tropical Impact. Monthly Weather Review, 125(1), 5-39.

Solano, F. J., E. J. Alfaro , \& A. Quesada. (2011). Impacto de los Ciclones Tropicales del Atlántico en América Central, Temporada de 1968 y 1969. Diálogos Revista Electrónica, 12(1), 81-100.

Soley, F.J. (1994). Suavizamiento de series cronológicas geofísicas con ruido blanco y rojo aditivo. Revista de Geofisica, 41, 33-58.

Srinivasan, J., \& Smith, G. L. (1996). Meridional Migration of Tropical Convergence Zones. Journal of Applied Meteorology, 35(8), 1189-1202.

Taylor, M. A., \& Alfaro, E. J. (2005). Central America and the Caribbean, climate of. In Encyclopedia of world climatology (pp. 183-189). Springer Netherlands.

Velásquez, R. (2000). Mecanismos físicos de variabilidad climática y eventos extremos en Venezuela (Licenciatura's thesis). San José, Costa Rica: Universidad de Costa Rica.

Vera, C., Higgins, W., Amador, J. A., Ambrizzi, T., Garreaud, R., Gochis, D., ... Zhang, C. (2006). Toward a unified view of the American monsoon systems. Journal of Climate, 19(20), 4977-5000.

Wang, C. (2007). Variability of the Caribbean Low-Level Jet and its relations to climate. Climate Dynamics, 29(4), 411-422.
Wang, C., \& Enfield, D. B. (2001). The Tropical Western Hemisphere Warm Pool. Geophysical Research Letters, 28(8), 1635-1638.

Wang, C., \& Enfield, D. B. (2003). A Further Study of the Tropical Western Hemisphere Warm Pool. Journal of Climate, 16(10), 1476-1493.

Wang, C., \& Fiedler, P. C. (2006). ENSO variability and the eastern tropical Pacific: A review. Progress in Oceanography, 69(2-4), 239-266.

Wang, C., \& Lee, S. (2007). Atlantic warm pool, Caribbean low-level jet, and their potential impact on Atlantic hurricanes. Geophysical Research Letters, 34(2), 1-5.

Wang, C., Lee, S.-K., \& Enfield, D. B. (2008). Climate Response to Anomalously Large and Small Atlantic Warm Pools during the Summer. Journal of Climate, 21(11), 2437-2450.

Wang, C., Lee, S., \& Enfield, D. B. (2007). Impact of the Atlantic Warm Pool on the Summer Climate of the Western Hemisphere. Journal of Climate, 20(20), 5021-5040.

Zárate-Hernández, E. (2013). Climatología de masas invernales de aire frío que alcanzan Centroamérica y el Caribe y su relación con algunos índices Árticos. Tópicos Meteorológicos y Oceanográficos, 12(1), $35-55$.

Zárate-Hernández, E. (2014). Influencia de las masas invernales de aire frío sobre el Chorro de Bajo Nivel del Caribe y sus ramas. Tópicos Meteorológicos y Oceanográficos, 13(2), 19-40.

Zhang, R., \& Delworth, T. L. (2006). Impact of Atlantic multidecadal oscillations on India/Sahel rainfall and Atlantic hurricanes. Geophysical Research Letters, 33(17), L17712.

Zhang, Y., Wallace, J. M., \& Battisti, D. S. (1997). ENSOlike interdecadal variability: 1900-93. Journal of Climate, 10(5), 1004-1020.

\section{See Digital Appendix at: / Ver Apéndice digital en: https://revistas.ucr.ac.cr/index.php/rbt}

